\title{
Some Vietnamese Viewpoints upon Second Language Acquistion Theories in Language Contact Environment
}

\author{
Tran Thi Thanh Dieu \\ Faculty of English Linguistics and literature, University of Social Sciences and Humanities, Viet Nam National University , Ho Chí Minh \\ City, Vietnam
}

Email address:

thdieu2003@yahoo.com (T. T. T. Dieu), thanhdieutt@hcmussh.edu.vn (T. T. T. Dieu)

\section{To cite this article:}

Tran Thi Thanh Dieu. Some Vietnamese Viewpoints upon Second Language Acquistion Theories in Language Contact Environment. International Journal of Language and Linguistics. Vol. 3, No. 4, 2015, pp. 222-229. doi: 10.11648/j.ij11.20150304.15

\begin{abstract}
This study focuses on the interference between the theories of second language acquisition by the native speakers (such as: Behaviorist's theory, Nativist's theory, Interactionist's theory, Information Processing theory, Vygotsky's theory, Halliday's theory, Sociolinguistic's theory) and the viewpoints of the non-native speakers (e.g. Vietnamese) who study a native language (e.g. English) as a second language or foreign language. Moreover, based on the summary table of the second language acquisition theories, the viewpoints of non-native speakers are analyzed to find out which theories adapt the viewpoints of the learners, being really the ones who acquire second languages. Last but not least, the effects of learning process and of learners on second language acquisition are explored for illustration.
\end{abstract}

Keywords: Imitation, Reinforcement, Reward \& Punishment, Habit Formation, Thinking, Self producing, Motivation

\section{Introduction}

Walt Whitman has put that "Language is not an abstract construction of the learned, or of dictionary-makers, but is something arising out of the work, needs, ties, joys, affections, tastes, of long generations of humanity, and has its bases broad and low, close to the ground" (2011: 429) [6]. This proves that it is not easy to study a language and more difficult to study a second language or a foreign language now that every language in the world has its own characteristics which are nearly completely different from one another. For instance, English tends to be a stress-timed language with rhythmic patterns based on a fairly regular recurrence of stressed syllables. However, Vietnamese tends to give equal weight to each syllable, making the rhythmic patterns appear to be more syllable-timed [1].

To solve this problem, many linguists have created their theories of second language acquisition, such as Behaviorist's theory, Nativist's theory, Interactionist's theory, Information Processing theory, Vygotsky's theory, Halliday's theory, Sociolinguistic's theory. However, most of them are native speakers with English as their mother tongue whereas nonnative language speakers (e.g. Vietnamese who study English) face lots of difficulties due to the differences in linguistic features and negative transference.
Therefore, being Vietnamese who study English as second language or foreign language in some cases, we would like to analyzed the effects of our learning process as well as learners on second language acquisition based on our beliefs about the nature of language, the learning process and our learners. These factors are explored both as individuals and as members of society, in the reflect understanding and thinking about the various theories of second language acquisition explored.

Nobody would think of questioning the advantages of these theories, but non-native speaker is a vexed question. We strongly believe in the effect of these second language acquisition theories. However, as a proverb goes: "Seeing is believing", we would like to do a research to prove the advantages of these theories and to find out which suitable to which phase of learning. We also hope to convince teachers to use these theories in teaching language in general and second language in particular.

\section{Aims and Theoretical Background of Research}

\subsection{Theoretical Background of Research}

Language is a system of interrelated terms, the underlying 
code which ensures that people can speak and understand each other [4]. It has social underpinning and is an operative system embedded in brain of everyone who has learnt a given language. This system is a network of relationships which characterized as being of the two kinds: "syntagmatic" (i.e. items are arranged in the consecutive, linear order) and associative, later termed "paradigmatic" (i.e. the organization of units in a deeper fashion dealing with grammatical and semantic relations) [6]. Language is emphasized as a system of (arbitrary signs and the central part of overall science of sign relations or semiotics (following CS. Peirce's terminology). Language as socio-semiotic presents language as functioning as an expression of and metaphor for, the social processes which it creates and the social contexts in which it occurs. Inherent in the socio-semiotic approach to language description is the notion of language as a dynamic process.

In the other words, language is a system of recourse (consisting of first, the simultaneous lexico-grammar (words and grammar) which has three aspects consisting of transitivity (things, even, circumstance, mood (structure, elements, theme-rheme, cohesion) and second, the generic structure of text) to make the three simultaneous meaning (consisting of idealtional-representing experience and logic as well as interpersonal-exchanging information and goodsand-services, expressing position and textual-organising the flow of information) in context. Therefore, language comprises both form and meaning that must be focused on the same level [5].

Therefore, we do not quite agree with the Behaviourist' $s$ point of view, which focused on the form of behavior since language form is made up of pattern and structure. Language patterns can be analyzed from the morphemes level right up to the whole discourse based on the order that the combination of morphemes to form words, then from words to phrases, to clauses, to sentences and up to discourses that have social purpose. The second important element is meaning that is influenced by the context in which language is used. Those are the context of culture (way of doing and thinking determined by environment) and the context of situation which are defined by field (activity, subject or topic), tenor (relationship between interactants) and mode (channel of communication - e.g. spoken, written).

In addition, our belief of language is highly influenced by Vygotsky's view that language is both object of learning as well as means of learning, used in all areas of learning including learning of language itself. He also considered language as social tool; object-regulation for mediation in learning, for others-regulation - primary instrument for imparting society's knowledge through talk in interaction or instruction as well as tool for self-regulation, primary instrument for sense-making or cognition through private or inner speech.

Last but not least, according to Halliday's point of view, language has three functions: Interpersonal function reflects the tenor of discourse, Ideational function reflects the field of discourse and Textual function reflects the mode of discourse [12]. As a result, our philosophy of the nature of language can be briefly expressed as follow:

Language is a uniquely human activity, a speaker is free to create new utterances, but in order to be understood, his utterances must remain within the "rules" established by the linguistic system of the community [5]. This view may has something that hardly in common with the behaviorist's perspectives which believed that language is defined by consistent formal patterns (e.g. sentence structure) in its users' speech or writing. In addition, language reflects the socio-cultural organization and environment of its speakers [12]. All languages have universal properties, signals for naming object in the environment (nominals) and for expressing action or status of being (verbal). As a result, it's hardly denied that Language is a system of conventional symbols used for communication and structuring the environment by a whole community[4].

Therefore, to analyze how languages in general and second languages in particular are acquired, some theories of language acquisition are summarized to be the theoretical background for this research [10][12], [13], [14].

Table 1. Some Theories of Learning Acquisition.

\begin{tabular}{|c|c|c|}
\hline No & Theory & Main points \\
\hline 1 & $\begin{array}{l}\text { Behaviorist's } \\
\text { theory }\end{array}$ & $\begin{array}{l}\text { - The language habit was formed by constant repetition \& reinforcement of the teacher. } \\
\text { - Imitation ("Stimulus \& Response") } \\
\text { - } \text { Inductive Hewabit Formation } \\
\text { - } \text { Operant \& conditioning } \\
\text { - IRF: initiate-response-feedback } \\
\text { - L2 : } \\
\text { - Imitation } \\
\text { - Operant conditioning \& Habit Formation } \\
\text { - } \quad \text { Exward \& Punishment } \\
\text { - } \text { recording and analysis of conversation in which the learner participate } \\
\rightarrow \text { Crucial diffence bet SLA\&L1 Acquisition } \\
\text { - Learner no longer "Tabula Rasa" } \\
\text { - L1 pattern already "habit" } \\
\text { L1 habit may INTERFERE with learning "correct" L2 pattern }\end{array}$ \\
\hline 2 & Nativist's theory & - Innate ability of human mind to make sense of things \\
\hline
\end{tabular}




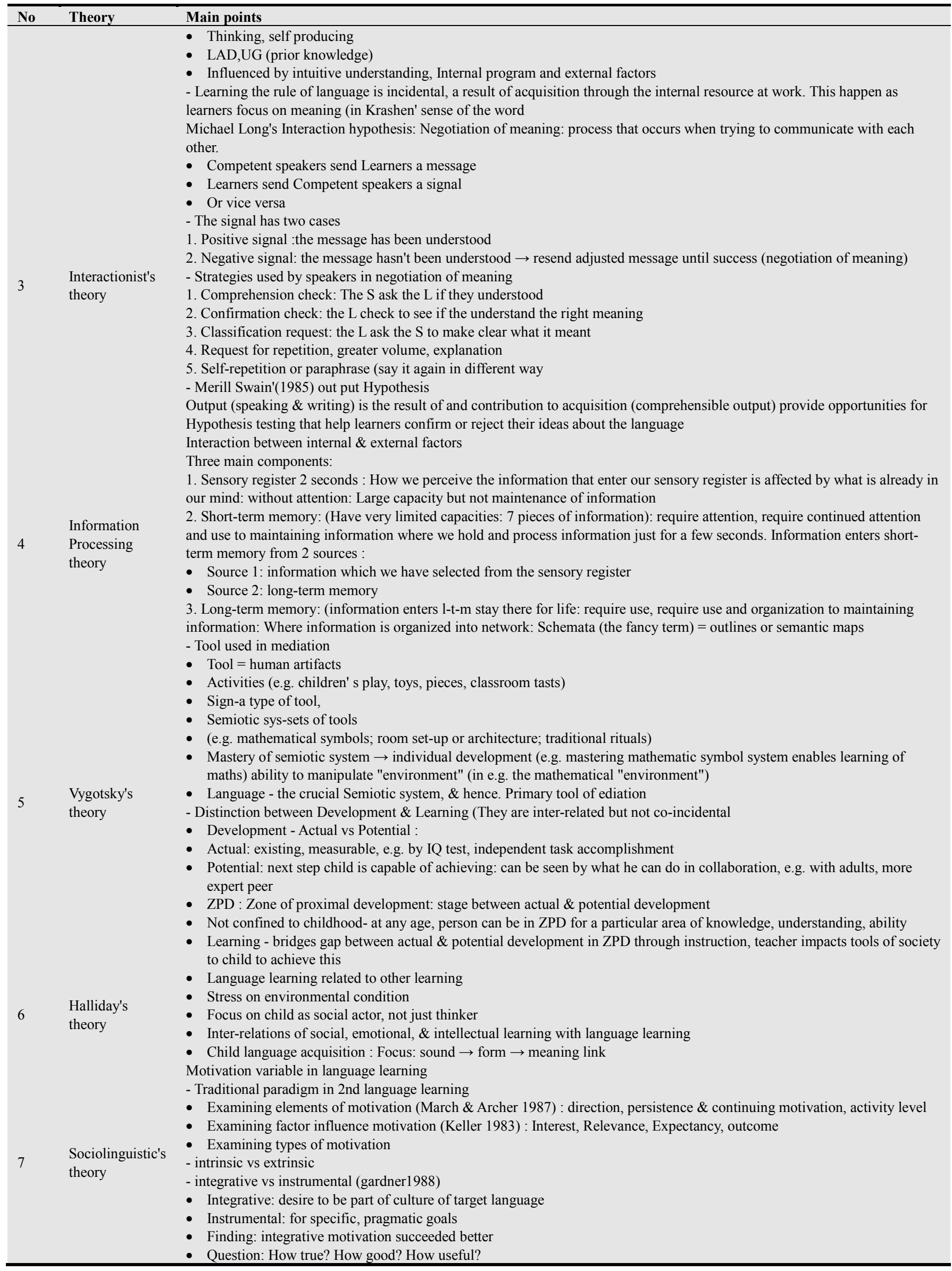




\begin{tabular}{|c|c|c|}
\hline No & Theory & Main points \\
\hline & & $\begin{array}{l}\text { - Importance of motivation in relation to SLA theory" } \\
\text { - Input \& intractionist theorist: search for comprehensible input } \& \text { participation in negotiation of meaning } \\
\text { - Information processing theorist: Motivation } \rightarrow \text { Attention }\end{array}$ \\
\hline
\end{tabular}

\subsection{Aims}

The interference between the theories of second language acquisition by the native speakers (such as: Behaviorist's theory, Nativist's theory, Interactionist's theory, Information Processing theory, Vygotsky's theory, Halliday's theory, Sociolinguistic's theory) and the viewpoints of the non-native speakers (e.g. Vietnamese) who study native languages (e.g. English) as second languages are analyzed to find out which theory is suitable for which phase in the learning process.. Moreover, based on the summary table of the second language acquisition theories, the effects of learning process and of learners on second language acquisition are explored to find out which theories adapt the viewpoints of the learners, being really the ones who acquire second languages.

\section{Methodology}

The research was conducted for twenty-four weeks from September 2012 to February 2013 with six weeks for preparation and choosing population, twelve-week trial teaching, one week for testing and three weeks for survey as well as the last two weeks for data analysis. The method used in the research is the comparative strategy based on the analysis of some second language acquisition theories and learners' viewpoints. Moreover, the combination of Quantitative approach to Check and compare the score, and Qualitative approach through the Questionnaire to check students' thinking has been used [11].

\subsection{Variables}

The research is largely the study of what happens when variables are systematically manipulated in planned combinations. In my research, Variables play the following roles

\subsubsection{Dependent Variable}

Some grammatical points, some lessons being used and the test-score for comparing learners levels before and after trying the teaching methods in different phases of learning, called the treatment.

\subsubsection{Independent Variable (Manipulated Variable)}

Some basic points of the Behaviorist's theory, Nativist's theory, Interactionist's theory, Information Processing theory, Vygotsky's theory, Halliday's theory, Sociolinguistic's theory on second language acquisition are used as teaching methods, which have been selected in order to study its effect on the dependent variable.

\subsection{Participants}

The research was carried out with 90 Vietnamese learrners (for each phase: beginners and intermediate) who were from
2 kinds of source: Beginner courses and intermediate courses in English - Foreign Language Center at the University of Social Sciences and Humanities and HCMC Open University, called "population" (in order to ensure the reliability of the effect of a strategy (from the Behaviorist's, Nativist's .... theories of second language acquisition), chosen randomly at the first phase of beginners and by being checked 2 grammatical Tests. Then samples of the students population were evaluated their progress and surveyed by questionnaire about their thinking after the method was used. Learrners have simply been providing their judgments and Checklist of Colleagues' observation and criticizing. Analysis of the experimental and survey data, checked whether students who received the treatments made lots of progress [8].

\section{Result of Research}

\subsection{Effects of Learning Process on Second Language Acquisition}

Learning process is a notion making us difficult to draw the philosophy because of what the subject of learning is. About language learning, our classification leads to many types of language such as: the mother tongue, the second language, the foreign language.., so the learning process must be different caused by the situation in which language is learnt [6], [8]. After comparing learners test scores, learners' thinking, we have made the following conclusions. In general, we can divide the learning process into two phases:

The first is for beginners who do not have background knowledge of the language they are studying so this phase is the phase of inputting knowledge. We think this is relevant to the Long-term Memory of The Information Processing Theory. This is the time for them to store up knowledge that will become the background knowledge (schemata) of the second phase. According to our experience when we started teaching English for the beginners, they find English difficult to pronounce so they were afraid of reading the words or repetition but they just wanted to speak English.

Therefore, when we asked them to read and learn by heart vocabularies, grammatical structures, they nearly refused and said that was an old method. But after a month of studying without memorizing vocabularies and grammatical structures, they made no progress. In addition, we let them discuss but they did not know what to speak because the beginners do not know anything about that language and of course they can not create anything, For this reason, we used this result to proved that their viewpoint upon how to learn a second language was wrong and insisted that their duty at this phase is trying to gain as much knowledge as possible, as a proverb goes "what in your mind is yours". Therefore, the question now is how to gain knowledge or new terms. The answer is remembering but the vexed question is how to remember a 
new term. At this point, we think the philosophy of the Behaviorist can give a help to answer this question as "One of the logical ways is imitation and repetition through observable behaviors with the two kinds of Reinforcement [12]:

\section{Reinforcement:}

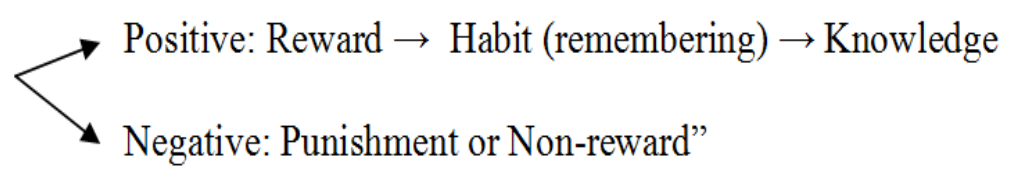

Figure 1. The Behaviorist philosophy of second language acquisition

At this phase, External Factors: Environment, teacher, materials are very important. It's rare to see anyone who succeeds in learning a foreign language themselves. Moreover, correction should be concerned so strictly because language is made of patterns and structure. No-one can deny that "interlingua transfer" error usually happens if the learners can not contrast the two points of grammar that have a part in common in the two languages. This leads to the fact that learners usually use knowledge of his L1 to produce the L2. After a long time this error will become habit that is too difficult to be changed. As a Chinese and Vietnams proverb says "Gian sơn dễ đổi bản tính khó dời" generally translated into English as "the King of the country can be replaced easily but changing someone's personality is very difficult".

The second phase is the phase of improving the language we have studied. With the background knowledge we have accumulated in the first phase, learners can become more self-controlled in their learning process in which people can create new, own sentences based on gained background knowledge. Therefore, at this stage, learning is not only imitation and drilling but also creating, so internal factor their brain (deep thinking)..... is also important. To apply this philosophy, my learners are advised to try to use their brain by deep thinking or thinking in English. Moreover, in our opinion, every other theory we have had chance to study has some points relevant to this. We will try to analyze this phase on the view of the theories which has influenced on the learning process through our own learning experience.

We are of the opinion that learning process is influenced by not only internal but also external factors. We believe in the existence of Language Acquisition Device (LAD), and Universal Grammar (UG) of the Nativist's point of view or the IQ as Vygosky's that can be regarded as the Internal factors. The external factors also play a very important role in learning process such as: environment, teacher's direction, materials, interest, relevance, expectancy, culture, condition, outcome, attitude, linguistic rules.... [12][14]. Moreover, according to the philosophy of the Socio-cultural Theory by Vygotsky, Halliday.. human activities and also result are defined by purpose. Three features of activity (Activity Theory) are Motivation, Action, Condition: Motivation define activity, action decided by condition, learning activities, therefore, must be defined by learning goals. Learning is cultural development from Inter-psychological (between mind) to Intra-Psychological (within mind): begins on social level before moving onto psychological level. That means when studying anything new, the learning process should happen in three steps to gain the mediation: From Object-Regulation to Other-Regulation to Self-Regulation. Without the Self-Regulation is like just looking at something without being sure that we can see it or not, Self-regulation is a step for learners to check themselves by doing on their own with deep thinking, the factor leading to cognition. We should base on the view: Zone of proximal Development (ZPD) of Vygotsky's philosophy to check the result of learning process [12].

We are also in favour of the view about the difference between 'learning process' and 'acquisition process'. Learning process is a more conscious process, but acquisition process is subconscious. Many people have the same learning process because they are studying in the same class, for instance, our students, but they have the different acquisition process because of different of innate ability of learning (different LAD-different innate ability of human mind to make sense of things- different IQ), different prior knowledge (background knowledge-UG), different way to study, different effort, different environment \& situation. And I think this is also the reason why there are many objects to homework [12]. They say that if the pupils are given the same homework but they do the homework in different situation, for instance, one does the homework in a very comfortable room with air-conditioning but the other must do the homework in a small house in a labour-area with noise, how can we compare the result and does the result really reflect the learners ability or quality?

We can see the importance of the situation in this case. If we live in a place where people use that language in communication, the progress will happen faster and more easily. For instance, the immigrants from Vietnam, we usually call them "the Vietnamese oversea", when they live in Vietnam they spoke English very badly, but since they came to America to live they have been able to speak much better. Therefore, communication or interaction is an important factor to gain input through Negotiation of meaning of Michael Long's Interaction Hypothesis with many strategy such as: comprehension check, Confirmation check, Classification request, Request for repetition, self repetition or paraphrase [12].

About the result of learning process, we find something logical in the Imput hypothesis of Nativist philosophy [14]. Comprehensible input must be $i+1, i+2$. $i+3$....Because " $i$ " is something like prior or background knowledge, without 
$" \ldots+1, \ldots+2 \ldots "$ no progress happen. This comprehensible enables acquisition and then output created (speaking, writing) is the result of and also the contribution to acquisition (comprehensible output) providing opportunities for Hypothesis testing that help learners confirm or reject their ideas about the language. This Output Hypothesis of Merill Swain gives a step to make the learning process become a circle with the main and last goal is Acquisition the language, illustrated as follows:

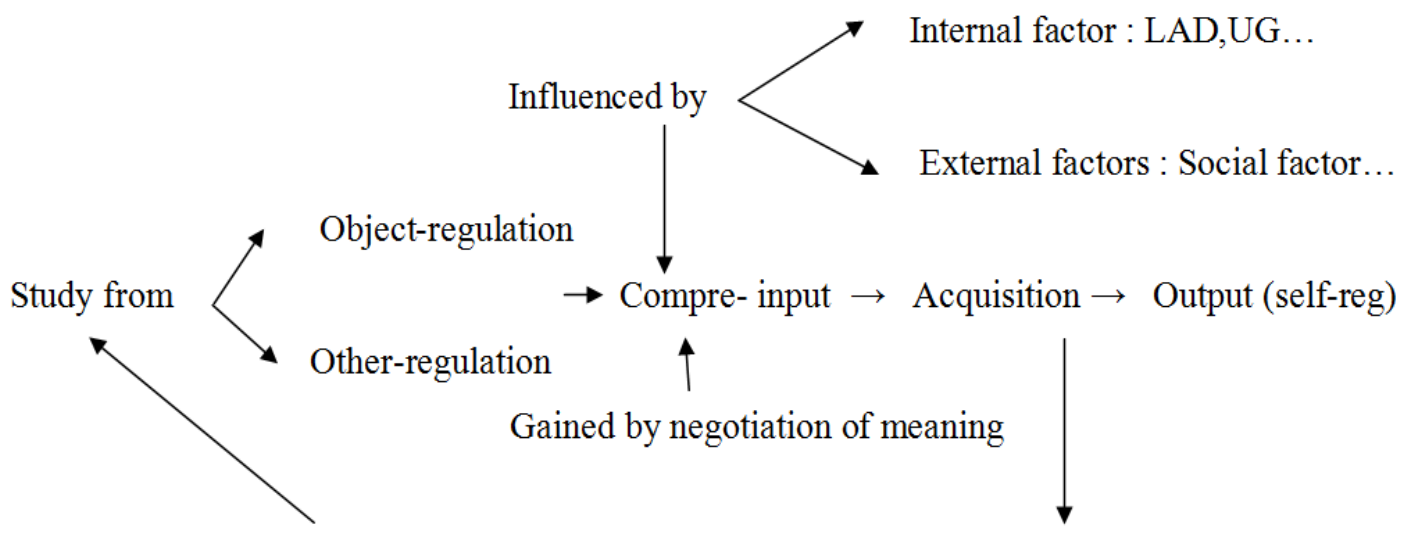

Use as background knowledge, object-reg, tool for learning other

subject or learning language itself

Figure 2. The Output Hypothesis of Merill Swain - Interactionist's theory.

In short, in our opinion, language learning should be divided into two phases: The first phases for beginners who are trying to store the background knowledge by behavioral observation then imitation by repeating and constant drilling until become habit. To a certain level, it's also the second phase, with enough knowledge of vocabularies, grammar rules...., learners will become more self-controlled to create their own sentences..... that are influenced by their background knowledge, feeling, emotion, attitude, and social, cultural factors as well as motivation.

\subsection{Effects of Learners on Second Language Acquisition}

Language learners are, first and foremost, human being. Therefore, through the experiment of teaching beginners and intermediate learners, using the points of some second language acquisition theories, we have found out the following points.

First, we would like to analyze the individual characteristics of the language learners. We do not quite agree with the Behaviorist view that people are like animals although they are more complex beings [12]. Our philosophy runs quite parallel to Cognitive here as we believe that human being has innate ability of human mind to make sense of thing and thinking (= cogitation) that makes people unique and different from animals. We also believe in the existence of the Language Acquisition Device (LAD), and Universal Grammar (UG) of the Nativist's point of view or the IQ as Vygotsky's that can be regarded as the Internal factors. But In my opinion, the view of Critical Period Hypothesis (CPH) is open to doubt. The interactions think that L2 is different from L1 because of the CP. When studying L2, the CP appears and learners must rely mainly on the external factor [12], [14].
Howerver, we usually wonder if there is the existence of Critical Period and especially the time when this happen. May we show our opinion on this point through our own experience of learning L1 and L2. In our opinion, people learn L1 better and quickly than L2 partially because of the context of using language. When learning the mother tongue, learners have more chances to listen to the language and use language everyday with all people in society and every minute with everyone in the family. That can be called constant repetition, constant practice. At this point, the Behaviorism is parallel to our view. But when studying L2, the chance of listening, speaking, practising and using language is fewer or in some case, it's rare and of course the result must be different, the progress is slower. We began studying the L2 (or exactly we call it the foreign language) at the age of 7 so we found difficult to remember the word or the grammar rule. However, when we little grew up, we felt easier to learn by heart and when we become older and older we could remember and especially understand the grammar rules of the foreign language more easily and quickly.

Moreover, after we gain some background knowledge, we could create our own way to master the rules to teach my own students. This happens not only to English but also to other subjects. When we were young, we found difficult to learn by heart the text in Vietnamese or to write a good essay. However, the older we are the better we compose the literary text. Therefore, we do not think the second or foreign language learning capacity is limited by the Critical Period. However, in our opinion, the ability of learning decreases when we become rather old, at the time our brains are so tired after a long time working so hard. It's also the time our body become biologically weaker because of old age, the 
biological rule. In the other word, it begins when we are old and our memory device can not work well anymore.

Another example is our learners' cases. They are at the same age and study in the same class, but their progress is different. Some have very good results, but some do not because they are different in the innate abilities of learning (different LAD, different innate ability of human mind to make sense of thing, different IQ). They also have different prior knowledge (background knowledge-UG), different ways to study, different efforts, different environments and situations [12]. This reminds us the second factor that also has strong influence on learner is the social factor.

Second, as Halliday's point of view, a child in particular and human being in general is a social factor, not just a thinker. Human being has the social characteristics because they are members of a particular family, community, and of course of society. We can say that language learner is a "social being". They are subjects that have feeling and emotion so they are certainly influenced by the external factors such as the culture, ethnicity.... The learner's social identity may be defined in terms of his nationality, socioeconomic class..... Therefore, no-one can deny that the social identity has a strong affect on his learning opportunities and practise, as well as his attitudes towards the language and hence, his motivations and capacity to learn it.

To illustrate this point of view, we can use the two cases of the Singaporean and Vietnamese, who learn English. They have different nationalities and live in the two different countries that have different attitudes towards English. Singaporeans almost consider English as their official language used very widely for many purpose: education, government and business..., so Singaporeans have more opportunities to use English. Moreover, they also have a clear purpose to study English that leads to the motivation and of course it's easier and quickly for them to get progress or fluency. Whereas in Vietnam, English is not widely used so Vietnamese quite naturally have few opportunities to use or to improve English. Therefore, they hardly have purpose for learning as well unless they are in special jobs or situations where they have to meet foreigners who speak English.

Last but not least, we would like to explore the importance of "Motivation" in the Sociolinguistic's theory, which contribute much to our learning. There are lots of factors that can play the role of Motivation: intrinsic and extrinsic, integrative and instrumental motivation reduced in a small word "purpose" [12]. No-one can doubt that our existence depends completely on our effort. However, what we can do is just concentrating all our best on studying to get as much knowledge as possible, the only hope from which we can use to apply for a job. Therefore, our purpose is knowledge, the factor helps us to earn for living. Knowledge is our desire so It may be called the "intrinsic motivation". In addition, the factor leading to our "intrinsic motivation" is our background, our situation, our fate ... which no-one can choose so it should be called "extrinsic". Moreover, we use our knowledge to earn for living so this is the "instrumental motivation". Last but not least, the desire of existence in the society is also the desire of integration. In short, we may point to the fact that "motivation" plays the very important role in our learning.

\section{Conclusion}

Nothing is more valuable than a logical point of view which helps finding a right belief leading to a right progress and a satisfied result. Therefore, this research has been done although many things may be still irrational in our points of view as non-native speakers learning second language. However, based on the viewpoint of language acquisition, and through our learners' and our own experience as learners, as well as language teachers, we have found that every theory is logical in a certain point. The Behaviourism has a contribution to the beginners' progress; whereas, the cognitive view is relevant to the learners at the second phase after they have accumulated enough background knowledge for their own creation of the language. The reason is that every language has its own rules of formation affected by not only what in human's mind as internal factors but also the external factors, the environment in which learners exist, following the view of Vygotsky and Halliday. As a result, we should not has a so strict critic on any theories despite their limit since no-one can deny that everything that has existed or used to exist has their own logical point. Sometimes we find it absurd, but time always passes so everything must be changed to make what we used to think logical become not logical anymore now because of the change of contexts. As a result, "Nếu ta bắn vào quá khư bằng súng luc, turơng lai sẽ bắn lại ta bằng đại bác" generally translated into English as "if we fire to the past by a gun, the future will fire to us by a cannon". As a result, as a proverb goes "we should not just see others' mistakes but be blind at our own" so what we should do is just analyzing everything to find their strength for us to apply and their weak points for us to prevent from.

\section{References}

[1] Aoyama, K. \& S. Guion, Prosody in second language acquisition. Acoustic analyses of duration and FO range: In O.-S. Bohn \& M. Munro, eds. Language experience in second language speech learning, In honor of James Emil Flege, John Benjamins: 281-297, 2007.

[2] Barker, George C. Growing up in a Bilingual community. The Kiva 17. 17-32, 1951.

[3] Bateman W. G. A child's progress in speech, with detailed vocabularies. Journal of Educational Psychology 5.307-20, 1914.

[4] Fromkin V, Roadman, Collins \& Blairs. An Introduction to Language. Second Australian Edition, 1990.

[5] Fromkin V, Roadman R, Hyams N. An Introduction to Language. Seventh American Edition, 2003.

[6] Fromkin V, Roadman R, Hyams N. An Introduction to Language. Nineth American Edition: Wadsworth Cengage learning, Canada, 2011. 
[7] Nguyễn Thiện Giáp, Các phương pháp nghiên cứu ngôn ngữ. Nxb Giáo dục, 2009.

[8] Hadley G. Action Research in Action: Singapore: SEAMEO Regional Language Center, 2003.

[9] Kent Bach \& Robert Hamish M. Linguistic Communication and Speech Acts. Mltpress, 1979.

[10] Phạm Ngọc, Phạm Đức Dương, Tiếp xúc Ngôn ngữ ở Đông Nam Á. Viện Đông Nam Á, Hà Nội, 1983.

[11] SEAMEO Regional Language Center, Research Methodology. Singapore: SEAMEO Regional Language Center, 2003.
[12] Seameo Regional language Center - Singapore, Language Acquisition. Social \& Psychological Dimension: SEAMEO, 2003.

[13] Bùi Khánh Thế, Lý thuyết tiếp xúc ngôn ngữ và vấn đề tiếp xúc ngôn ngữ ở Việt Nam. Cơ sở Đào tạo Sau đại học - Viện Khoa học Xã hội tại TP. Hồ Chí Minh, 1997.

[14] Uriel Weinreich, Language in contact: Findings and problems. Newyork, 1953. 